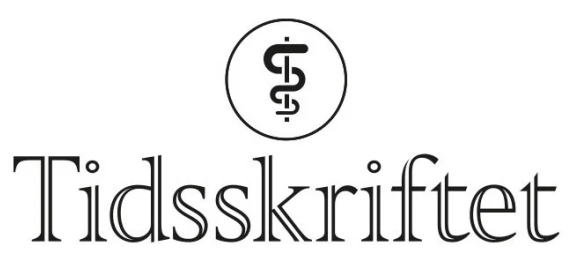

DEN NORSKE LEGEFORENING

\title{
Velskrevet bok om håndkirurgi
}

\author{
ANMELDELSER
}

PETTER MORTEN PETTERSEN

Lege i spesialisering i ortopedisk kirurgi, Sykehuset $\emptyset$ stfold

Leiv M. Hove, Vilhjalmur Finsen, Torstein Husby et al.

Håndkirurgi

413 s, tab, ill. Bergen: Fagbokforlaget, 2021. Pris NOK 659

ISBN 978-82-450-3554-4

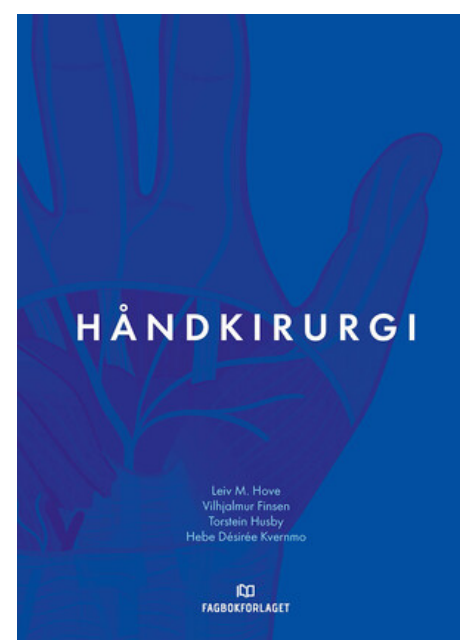

Håndkirurgi er et fag i utvikling, og en oppdatering av den norske læreboken i håndkirurgi har derfor vært etterlengtet. Denne nye utgaven er en solid lærebok som gir en pedagogisk, grundig og oversiktlig innføring.

Håndkirurgi inneholder 43 kapitler, hvor kapittelstrukturen varierer noe. Avsnittene er ikke for lange og gir en god struktur og progresjon gjennom de ulike temaene. Introduksjon, anatomi, patofysiologi, anamnese, diagnostikk, behandling og en avsluttende konklusjon er en gjennomgående oppbygning. Temaer som primær håndtering av håndskader, lys våken håndkirurgi, distale underarmsfrakturer og håndterapi har nå fått sine fortjente kapitler, og dette løfter denne reviderte utgaven til et nytt nivå. De aktuelle operasjonsteknikkene beskrives kort og konsist. 
Boken henvender seg først og fremst til leger i spesialisering i ortopedisk kirurgi og plastikkirurgi, men kan også leses som pensumbok for norsk diplom i håndkirurgi, skriver forfatterne i forordet.

Antallet forfattere er utvidet fra 19 i første utgave til hele 43. I forordet blir det klart at det har vært ønskelig å inkludere en ny generasjon norske håndkirurger i arbeidet. Inntrykket de etterlater, er at kapitlene er skrevet av svært kyndige forfattere, som ikke skriver for å fremme sine personlige kunnskaper og preferanser, men for å fremme faget og forståelsen for håndkirurgi blant sine yngre kollegaer.

Teksten er skrevet på godt norsk og er ikke for kompleks for målgruppen. Boken har et stort antall informative fotografier, røntgenbilder, skisser og illustrasjoner som fungerer som et godt supplement til teksten. Helhetsinntrykket hadde blitt løftet enda et hakk dersom de mange anatomiske tegningene var ført med samme penn.

Boken stimulerer til lengre leseøkter, men vil også fungere utmerket som et praktisk oppslagsverk i en travel arbeidshverdag. Anbefales!

Publisert: 13. desember 2021. Tidsskr Nor Legeforen. DOI: 10.4045/tidsskr.21.0754

(C) Tidsskrift for Den norske legeforening 2023. Lastet ned fra tidsskriftet.no 26. april 2023. 